DOCTRINA

\title{
Libertad personal y seguridad individual. Una revisión del artículo 19 número 7 de la Constitución Política de Chile
}

\author{
Personal freedom and individual security. A study of article 19 \\ number 7 of the Chilean Constitution
}

\section{Rocío Lorca Ferreccio \\ Universidad de Chile}

RESUMEN Este artículo consiste en un estudio general del artículo 19, número 7, de la Constitución Política de Chile. El objetivo de este estudio no solo es actualizar y sistematizar el estado de la discusión sobre los conceptos centrales de dicha disposición, sino también sobre los principales problemas de aplicación e interpretación de cada una de sus reglas. Además, el artículo plantea algunas preguntas o problemas que podrían surgir de cara al nuevo contexto social y político en el que la disposición ha de aplicarse.

PALABRAS CLAVE Libertad personal, seguridad individual, derechos fundamentales, Constitución Política de Chile.

ABSTRACT This work constitutes a general revision of article 19, number 7, of the Chilean Constitution. The central aim of such a study is to update and reorganize the state of the debate regarding its basic concepts as well as regarding the issues of application and interpretation that the article triggers. Aditionally, the articule raises certain questions that may arise on the face of the new social and political context in which this rule is meant to apply.

KEYWORDS Personal freedom, individual security, constitutional rights, chilean Constitution. 


\section{Introducción}

El artículo 19, número 7, de la Constitución Política de la República asegura a todas las personas el derecho a la libertad personal y a la seguridad individual, de manera similar a lo que establecen el artículo 9 del Pacto Internacional de Derechos Civiles y Políticos de 1966, y el artículo 7 de la Convención Americana de Derechos Humanos de 1969. Se trata de una norma muy extensa que tiene una vital importancia tanto conceptual como práctica.

En relación con su importancia conceptual, las definiciones que esta norma formula o invita a formular son centrales para comprender la concepción que una determinada comunidad política tiene sobre los individuos y su relación con las agencias que ejercen poder político. En términos prácticos, se trata de una norma muy importante, ya que sus reglas admiten una aplicación concreta particularmente efectiva. Esto es así tanto por el alto nivel de precisión de sus reglas, como por el hecho de que cuenta con una acción constitucional específica: el recurso de amparo regulado en el artículo 20 del mismo texto constitucional.

Dada la importancia conceptual y práctica de esta regla, este artículo tiene como objetivo tanto sistematizar su contenido como las cuestiones de interpretación y aplicación a que ha dado lugar esta norma, dando particular atención a los problemas que han surgido o han de surgir de cara al nuevo contexto social y político en el que la norma se inserta. En atención a estos fines, este artículo no problematiza un asunto en particular, sino que busca servir como marco de análisis tanto para el estudio de la regulación constitucional de la libertad personal y seguridad individual en Chile, como para el ejercicio de este derecho. En términos de su organización, a excepción de una primera sección de carácter conceptual, las secciones de este artículo se corresponden con los literales de la disposición constitucional y siguen su orden. El artículo finaliza con dos secciones generales, una sobre titulares y otra sobre destinatarios de la norma que se analiza.

\section{Objeto de regulación: La libertad personal y la seguridad individual}

En términos históricos, la norma puede reconducirse a la famosa cláusula 39 de la Magna Carta de Juan Sin Tierra de 1215, que estableció que ningún hombre libre puede ser privado de su libertad o de sus derechos a menos que así sea ordenado por un juicio legal conducido por sus pares o porque así lo ordene la ley. ${ }^{1} \mathrm{Si}$ bien esta extensa disposición constitucional se concentra en regular con bastante especificidad

1. En su formulación original: «Ningún hombre libre puede ser retenido, encarcelado, desposeído, perseguido o exiliado o dañado en modo alguno, ni tampoco solicitado o requerido, sino mediante un legítimo juicio de sus pares o por la ley de su tierra». El texto completo de la Magna Carta puede verse en British Library, «English translation of Magna Carta», 28 de julio de 2014, disponible en bit.ly/3glcgaX. 
las formas legítimas de afectación de la libertad ambulatoria o de desplazamiento, los conceptos de libertad personal y seguridad individual se caracterizan por una mayor amplitud e imprecisión que la idea de libertad ambulatoria. Pareciera que la razón por la cual la norma se dedica principalmente a regular esta última dimensión de la libertad personal es que es un presupuesto fundamental para el ejercicio de otras de sus dimensiones, y además se manifiesta históricamente como el espacio en que las personas se encuentran más vulnerables a los abusos en que puede incurrir el Estado y sus agencias coactivas.

En efecto, las limitaciones y protecciones que recibe el derecho a la libertad ambulatoria configuran de manera esencial la naturaleza de la relación política y la forma de vida que es posible en el contexto de una determinada comunidad. Esto se vuelve evidente en el hecho de que el poder ejecutivo y el poder de declarar estados de excepción constitucional se materializan, en último término, en la capacidad de restringir nuestra libertad de desplazamiento, como se desprende de la descripción de los estados de excepción constitucional contenida en el artículo 43 de la Constitución Política de la República. ${ }^{2}$ Si en algún momento el reconocimiento del poder del soberano dependía de su capacidad para determinar quién vivía y quién moría, en el Estado moderno reside de manera paradigmática en su capacidad de restringir y administrar nuestros cuerpos y nuestra libertad de desplazamiento (Foucault, 2007: 163-176).

No obstante, de esta especial preocupación por la libertad ambulatoria no se sigue que la norma no proteja en todo caso la libertad personal y la seguridad individual en términos más generales, de ahí que sea necesario precisar en qué consisten estos derechos. Conceptualmente, la libertad personal, en cuanto derecho, simplemente no puede consistir en un derecho a la libertad en el sentido indiscriminado de tener el derecho a hacer todo lo que uno quiera hacer con un deber correlativo de los demás a no impedir que uno haga todo lo que quiera hacer. ${ }^{3}$ Parece más acertado vincular la idea de un derecho a la libertad personal con la idea de autonomía, es decir, como un derecho a determinar de manera independiente cómo queremos vivir nuestras vidas y a tener la capacidad de llevar a cabo dicho plan de vida en la medida que sea legítimo de cara a la autonomía de los demás (Raz, 1988: 246-264; Taylor, 1986: 100-111).

Que el derecho a la libertad personal consista en un derecho a la autonomía o autodeterminación, implica un deber correlativo de no obstaculizar nuestra posibilidad de llevar adelante un plan de vida legítimo, el que no solo debe traducirse en un deber negativo de no interferir de manera inmediata y directa en la esfera de organización de otro, sino también en un deber positivo que obliga al Estado a establecer las condiciones que permiten que las personas tengan una oportunidad real de llevar adelante

\footnotetext{
2. Para una idea general sobre el estado de excepción, véase Schmitt (2009: 13-20).

3. En efecto, para algunos como Dworkin (1986: 297 y ss.), uno no tiene en ningún sentido relevante un «derecho» a la libertad.
} 
sus legítimos planes de vida. ${ }^{4}$ Esto no implica adherir a una concepción positiva de la libertad en los términos propuestos por Isaiah Berlin, en la medida que uno puede sostener que hay formas de interferencia cuya superación requieren la prestación de ciertos servicios y bienes por parte del Estado. La extrema pobreza, por ejemplo, no es solo una condición material en la que se encuentran ciertas personas, sino una forma de interferencia en la esfera de autonomía de otro, toda vez que el dinero no es simplemente un objeto material sino, como lo sostuviera Cohen, poder social (Cohen, 2008).5 En esa medida, superar condiciones de extrema pobreza podría ser entendido como una condición necesaria para la autonomía y para el aseguramiento de la libertad personal.

Por su parte, la seguridad individual, más que consistir en un derecho, alude a la existencia de un contexto de confianza que hace posible que una persona pueda autocomprenderse como un ser autónomo, en el sentido de no estar sometido a restricciones arbitrarias en su capacidad de determinar un plan de vida y ejecutarlo o a cualquier forma de abuso de poder por parte de la autoridad. La importancia de este contexto para el ejercicio de la libertad personal puede iluminarse mediante la idea de libertad como ausencia de dominación, donde la libertad no se entiende restringida simplemente por la limitación de opciones disponibles para un agente, sino por el sometimiento de nuestras opciones al arbitrio de otro, es decir, a una voluntad ajena que está controlada solo por sus propias preferencias y deseos. El ejemplo más claro de cómo la ausencia de seguridad impide que un sujeto pueda autocomprenderse como libre o autónomo es el del «amo benevolente» propuesto por Philip Pettit, en que el dueño de un esclavo lo trata como si fuera un hombre libre, pero no puede decirse que sea libre en la medida en que el amo podría, en cualquier momento y por cualquier razón, dejar de tratarlo así y comenzar a tratarlo como a un esclavo (Pettit, 1997: 22-23).

4. En el contexto de la filosofía política liberal, esto aparece como una de las funciones primordiales o esenciales del Estado. En efecto, como la función que le brinda legitimidad frente a quienes se encuentran sujetos a su poder. En este sentido, véase Rawls (2001) y Nagel (2005; 2008).

5. Es importante desmarcar la cuestión sobre si un derecho acarrea deberes correlativos de carácter positivo o negativo de la distinción que hiciera Isaiah Berlin entre libertad positiva y libertad negativa, ya que hay ciertas formas de interferencia (como suele ocurrir en las formas de injusticia estructural) cuya única manera de superación es mediante prestaciones positivas. Es decir, para evitar una interferencia en la autonomía de otro puede ser necesario realizar una prestación positiva a su favor. A esto se refiere Cohen (2008) cuando sostiene que la pobreza es una forma de interferencia de modo que las políticas de redistribución económica, por ejemplo, no necesariamente deberían fundarse en una concepción positiva de la libertad. En el caso de la pobreza, esto es así porque en una sociedad capitalista y neoliberal el dinero no es una cosa material o una capacidad, sino poder social, es decir, una forma de poder que es social en el sentido de que es diseñado y definido precisamente como una manera de evitar la interferencia en el acceso a bienes. En relación con esto, véase Berlin (1986) y Waldron (2009). 
Desde el punto de vista de los conceptos de libertad personal y seguridad individual, cobra sentido que el artículo 19, número 7 , dedique la mayoría de sus reglas a proteger la libertad ambulatoria en la medida que la posibilidad de decidir libremente donde poner el propio cuerpo es una condición esencial para el ejercicio del abanico de facultades que nos permiten diseñar y realizar nuestro plan de vida. Nuestro cuerpo y el lugar donde nos encontramos es el espacio material donde podemos desenvolver nuestra personalidad con todos sus atributos intelectuales, físicos y normativos. Como corolario de lo anterior, es también el espacio privilegiado en el que la arbitrariedad y el abuso de poder pueden llegar a expresarse.

\section{Libertad ambulatoria y regulación de la migración}

La letra a) del artículo 19, número 7, de la Constitución Política de la República, establece el derecho a la libertad ambulatoria como un derecho a:

Residir y permanecer en cualquier lugar de la República, trasladarse de un lugar a otro y entrar y salir de su territorio, a condición de que se guarden las normas establecidas en la ley y salvo siempre el perjuicio de terceros.

Como se señaló en la sección anterior, la libertad de desplazamiento o libertad ambulatoria es una dimensión especialmente relevante de la libertad personal, ante todo porque la decisión de dónde estar o dónde poner el propio cuerpo aparece como una condición esencial para el ejercicio de nuestra autonomía. Pero además de esta imagen de la libertad ambulatoria como una prerrogativa individual, la posibilidad de decidir dónde estar físicamente es fundamental de cara a la dimensión social de nuestra autonomía, toda vez que muchas veces las personas organizan sus vidas en relaciones íntimas de apoyo y colaboración, de modo que el éxito de sus proyectos personales y la calidad de su vida dependen de la cercanía física con ciertas personas, como sus familiares, amigos, vecinos, etcétera.

Estas redes de soporte o ayuda pueden ser tan fundamentales para el desarrollo de nuestros planes de vida que la incapacidad de determinar el lugar donde uno vive se ha llegado a considerar como un indicador de pobreza o de injusticia económica, ya que determina nuestra cercanía a redes de cooperación que robustecen nuestra libertad entendida como autonomía (Cordelli, 2015). ${ }^{6}$ Así, uno podría sostener que los procesos de aburguesamiento o gentrificación que caracterizan a la mayoría de las grandes urbes y que consisten en una persistente expulsión de las personas más pobres a áreas suburbanas que ellas no necesariamente eligen, afectan nuestra libertad ambulatoria de manera relevante toda vez que nos desvinculan de redes de apoyo

6. En este sentido, véase la importancia que Martha Nussbaum (1999) atribuye a las relaciones sociales para definir su lista de capabilities bajo la idea de afiliación. 
social que son relevantes para el ejercicio de nuestra autonomía. ${ }^{7}$ De ahí que en varios países se hayan adoptado regulaciones a las rentas para evitar la expansión desmesurada de estos procesos de aburguesamiento (Radin, 1986).

No obstante, más allá de esta afectación al desplazamiento dentro del territorio de la República, quizás el aspecto más relevante de esta disposición dice relación con el alcance de la protección de este derecho a personas de nacionalidad extranjera. Uno de los espacios en los que el ejercicio de la libertad de desplazamiento se vuelve más problemático es en la libertad para entrar y salir del país para quienes no son ciudadanos. Si bien a la fecha de este artículo no existen cifras claras sobre la cantidad de migrantes en Chile, todo indica que la cantidad de personas extranjeras que ingresan con ánimo de permanecer por un tiempo indefinido en el país ha ido aumentando de manera exponencial en los últimos años, lo que ha puesto presión sobre las reglas que regulan la migración (Lawson y Rodríguez, 2016; Rojas y Silva, 2016).

Las normas vigentes que regulan la migración en Chile se encuentran principalmente en el Decreto Ley 1.094 de 1975 y en su reglamento contenido en el Decreto 597 del Ministerio del Interior de 1984. Como puede deducirse a partir de las fechas de las mencionadas normas, estas fueron dictadas durante la dictadura de Augusto Pinochet en un contexto demográfico y político radicalmente opuesto al actual (Bassa y Torres, 2015: 103 y ss.). En efecto, por una parte sus normas expresan la ausencia de una necesidad de dar acogida a una gran cantidad de personas extranjeras en busca de un lugar para vivir y, por otra, la ausencia de un compromiso con los principios de un Estado democrático de derecho. El espíritu de la regulación parece ser, en cambio, la protección de la seguridad nacional, lo que explica por qué sus disposiciones están lejos de cumplir con los estándares internacionales sobre migración que encuentran su fundamento en los derechos humanos (Bassa y Torres, 2015: 107-109). Por razones de extensión, no es posible brindar un análisis pormenorizado de esta regulación y sus problemas de legitimidad. Estos, por lo menos, implican problemas frente a la garantía de igualdad y a las garantías de reserva de ley y debido proceso que corresponde aplicar frente a la restricción de derechos constitucionales. ${ }^{8}$ Un breve análisis del procedimiento de expulsión quizás puede servir para ilustrar parte de estos problemas, ya que su regulación parece asumir implícitamente que los migrantes carecerían de un derecho a la libertad ambulatoria igualmente robusto que el de las personas nacionales. $\mathrm{Si}$

7. Si bien la gentrificación no ha sido un tema demasiado discutido en relación con las ciudades latinoamericanas, ya existen una serie de trabajos que dan cuenta de que un fenómeno de aburguesamiento y expulsión empieza a ocurrir en nuestras ciudades, aunque con importantes diferencias con respecto al caso europeo. En este sentido, véase Casgrain y Janoschka (2013), López-Morales (2013), y Sabatini, Robles y Vásquez (2013).

8. Para un análisis más detallado sobre los problemas de legitimidad que afectan a nuestra regulación vigente, véase Basa y Torres (2015). 
esto fuera cierto, la normativa infringiría la disposición constitucional del artículo 19, número 7 , toda vez que sus disposiciones están orientadas a brindar protección a «todas las personas» sin reconocer un estatuto diferenciado para nacionales o extranjeros. Algo que ya ha sido expresamente declarado por nuestro Tribunal Constitucional frente a algunas de sus disposiciones. En efecto, dicho tribunal ha considerado que las distinciones realizadas bajo la categoría de extranjero son sospechosas de implicar una discriminación arbitraria, y por eso su legitimidad depende de que exista una justificación especialmente seria fuerte para dicha distinción (Bassa y Torres, 2015: 113-114).

De acuerdo con el artículo 84 del referido Decreto Ley, le corresponde al Ministerio del Interior decretar la expulsión de los migrantes a quienes se les haya rechazado o revocado una solicitud de residencia, mientras que la expulsión será dictada por los intendentes en relación con personas que se encuentren en una situación migratoria irregular, lo que corresponde a la mayoría de los casos de expulsión (Lawson y Rodríguez, 2016: 223). En términos materiales, esta orden supone una afectación absoluta de la libertad ambulatoria, lo que tiene importantes efectos en la autonomía de una persona, como ya se ha mencionado. Sin embargo, más allá de establecer la autoridad competente para decretarla y una cantidad algo exagerada de circunstancias de procedencia, el legislador no ha establecido un procedimiento que dé cuenta de su gravedad y que someta la adopción de esta medida a los principios mínimos de un debido proceso, que aseguren que la autoridad administrativa no actúe de manera arbitraria o injustificada.

En efecto, la ley permite la expulsión automática de una persona sin darle el derecho a ser oída por la autoridad que la expulsa, bastando un informe de la Policía de Investigaciones para que la expulsión se decrete. ${ }^{9}$ Frente a las órdenes de expulsión dictadas por el Ministerio del Interior, es decir, las relacionadas con migrantes que no se encuentran en una situación irregular, cabe un recurso judicial de reclamación que debe presentarse en un plazo de 24 horas ante la Corte Suprema, la que debe conocer y fallar de manera breve y sumaria. Mientras conoce de este recurso, la orden de expulsión debe suspenderse y el solicitante se encontrará detenido en un establecimiento penitenciario o en el lugar que la autoridad administrativa determine. Dado que la mayoría de los casos de expulsión no responden a esta hipótesis (ser dictados por el Ministerio del Interior), este recurso no se encuentra disponible para la mayoría de los migrantes. ${ }^{10}$

Otro problema de la institución de la expulsión dice relación con la amplitud de sus condiciones de procedencia. ${ }^{11}$ En efecto, a pesar de lo intenso de la medida, esta

9. Sobre deficiencias de legitimidad de los procedimientos a que da lugar la actual Ley de Extranjería, véase Basa y Torres (2015: 117-119).

10. Para un análisis en profundidad, véase Lawson y Rodríguez (2016).

11. Para un análisis sobre los amplios márgenes de discrecionalidad administrativa que existen en esta 
aparece como una sanción que puede decretarse para la mayoría de las infracciones a la regulación de la migración, y no como una medida de último recurso, estableciendo un régimen bastante severo y debilitando con ello el contenido específico del derecho a la libertad personal de los migrantes, ya que arriesgan su total privación con casi cualquier descuido (Lawson y Rodríguez, 2016: 223).

A las facultades generales otorgadas a la autoridad administrativa, además se suma la facultad que la Ley 18.216 de 1983, reformada por la Ley 20.603 de 2012 , le ha conferido a los jueces penales para decretar la expulsión del territorio nacional a los extranjeros sin residencia legal que fueren condenados a una pena igual $\mathrm{o}$ inferior a cinco años de presidio o reclusión menor en su grado máximo. De acuerdo con el artículo 34 de la referida ley, esta pena sustitutiva puede imponerse de oficio o a petición de parte. La pena sustitutiva acarrea además la prohibición de ingresar al territorio nacional en un plazo de diez años contados desde la sustitución de la pena.

A primera vista, uno pudiera pensar que esta medida opera en beneficio de los extranjeros toda vez que les permite evitar el cumplimiento efectivo de la pena privativa de libertad, sin embargo, en la práctica establece un trato diferenciado que puede perjudicarlos toda vez que ellos también podrían beneficiarse con penas sustitutivas que no implican la obligación de salir del país y no regresar por diez años, como por ejemplo la remisión condicional, la libertad vigilada u otra de las medidas enunciadas en el artículo 1 de la Ley 18.216 en tanto cumplan con los requisitos que ellas establecen.

En suma, una breve mirada a la regulación de la migración en Chile denuncia la falta de reconocimiento institucional a la igualdad de personas extranjeras y nacionales frente a la protección constitucional de su libertad personal. Existen una serie de prácticas jurídicas en las que se ha expresado y declarado la igual protección en sus derechos que merecen los migrantes. Así, en algunas intendencias se ha aplicado la Ley 19.880 de 2003 para subsanar la falta de estándares procesales para la imposición de la sanción de expulsión. Por su parte, los tribunales superiores han acogido varios recursos de amparo para proteger la afectación de la libertad ambulatoria de los migrantes y con ello han ampliado de manera significativa el uso de esta acción constitucional. ${ }^{12}$ Y, finalmente, el Tribunal Constitucional ha acusado la deficiencia de nuestra legislación (Henríquez Viñas, 2014). Sin embargo, estas prácticas no tienen la regularidad que exige una protección seria de la libertad ambulatoria de los migrantes que debería expresarse en una normativa legal de carácter general que

regulación y los problemas que esto plantea de cara a la igualdad ante la ley, véase Basa y Torres (2015: 114-117).

12. Para un análisis sobre el uso de la acción de habeas corpus para recurrir frente a expulsiones ilegales o arbitrarias, véase Henríquez Viñas (2018). 
limitara los niveles de desprotección, indiferencia y arbitrariedad que caracterizan el trato institucional que reciben los migrantes en nuestro país (Díaz Tolosa, 2014).

\section{Reserva legal de afectación legítima}

El literal b) del artículo 19, número 7, establece la principal garantía para proteger la libertad personal y la seguridad individual, es decir, el establecimiento de una regla de legalidad de acuerdo con la cual una persona solo puede ser privada de su libertad o verla restringida «en los casos y en la forma determinada por la Constitución y las leyes». Esta norma ha tenido su mayor desarrollo en el ámbito de la teoría del derecho penal moderno, cuyo principio fundacional es el principio de legalidad de los delitos y las penas, popularizado en la formulación latina propuesta por Anselm von Feuerbach (1989: 63 y ss.): Nullum crimen, nulla poena, sine legem. Además, esta norma se encuentra recogida en el numeral tercero del artículo 19 de la Constitución Política de la República, así como en el artículo 18 del Código Penal. Sin perjuicio de que en su evolución histórica la reserva legal se ha identificado primeramente como un límite al ejercicio del poder punitivo estatal (y también al poder de cobrar impuestos), la reserva legal es una garantía de carácter general para la restricción de derechos fundamentales de acuerdo con lo dispuesto por los artículos 19, número 26; 32, número 6; y 63 de la Constitución chilena.

La reserva de ley en tanto regla de distribución de competencia entre la postestad normativa del legislador y la potestad normativa del poder ejecutivo, establece que corresponde exclusivamente al legislador, como representante de la voluntad soberana, autorizar limitaciones o restricciones a las garantías y derechos individuales constitucionalmente consagrados. Determinar el alcance preciso de esta garantía ha demostrado ser un asunto bastante controvertido y complejo, de ahí que, para no alejarnos del ámbito de análisis de este artículo, en lo que sigue me concentraré en los fundamentos y alcances de la reserva de ley en el contexto específico de la libertad personal y seguridad individual frente al ejercicio del poder punitivo estatal. ${ }^{13}$

Existe una serie de fundamentos y finalidades para la reserva legal como condición formal de cualquier privación de libertad legítima. La consideración de dichos fundamentos excede los límites de este artículo, pero es importante considerar que, en concordancia con la idea de seguridad individual recién expuesta, los principales fundamentos del principio de legalidad son el control de la arbitrariedad y la configuración de un contexto de certeza y confianza frente a las actuaciones de las agencias coactivas del Estado, así como dotar de legitimidad democrática a las normas que autorizan la privación de libertad de una persona. Este último fundamento explica

13. Para una revisión general de la reserva de ley, véase Nogueira (2003 y 2005), Cazor y Pfefer (2009), y Cordero (2009). 
que la reserva legal debe entenderse referida a la ley en sentido estricto, es decir, a las normas emanadas del poder legislativo que de acuerdo con el artículo 1 del Código Civil expresan la voluntad soberana del pueblo.

Es importante considerar que el fundamento de la garantía de reserva legal también se relaciona o encuentra parte de su sentido en otra disposición del artículo 19, en la norma que establece la presunción de inocencia. ${ }^{14}$ Esto es así porque en adición a consideraciones de certeza y legitimidad democrática, la exigencia de legalidad opera como una condición necesaria para el juicio de culpabilidad que debe anteceder a toda pena estatal legítima. De acuerdo con las tradicionales condiciones de legitimidad del derecho penal en un Estado democrático, solo puede haber un juicio de culpabilidad donde existe una norma de comportamiento que sea conocida por el sujeto con anterioridad a la realización de la conducta, o que por lo menos se trate de una norma de comportamiento que este haya podido conocer. ${ }^{15}$

Cabe destacar que a pesar de lo establecido por la regla constitucional en comento, la regulación de la ejecución de las órdenes judiciales de privación de libertad en los establecimientos penitenciarios no se encuentra regulada en una ley en sentido estricto, sino en un reglamento. Esta situación es evidentemente problemática y expresa un déficit de legitimidad del sistema penal chileno que ha sido denunciado con insistencia por parte de académicos, jueces y organizaciones civiles sin que haya sido subsanado por el legislador hasta el momento. ${ }^{16}$

\section{La detención y el arresto}

La letra c) del artículo 19, número 7, de la Constitución Política de la República establece que tanto el arresto como la detención solo proceden cuando existe una orden de autoridad competente que le haya sido intimada en forma legal al arrestado o detenido. A continuación, la norma regula la detención por flagrancia, así como los plazos en los que el detenido debe ser puesto a disposición de un juez competente.

El arresto básicamente consiste en una institución legal a través de la cual se restringe la libertad personal de un individuo, privándolo por un período breve de su libertad ambulatoria. En general opera como una medida de apremio que los tribu-

14. Véase el inciso 7 del artículo 19, número 3, de la Constitución Política de la República, el artículo 8 de la Convención Americana sobre Derechos Humanos y el artículo 14 del Pacto Internacional de Derechos Civiles y Políticos.

15. De ahí que a diferencia de lo que ocurre en el ámbito de la responsabilidad moral para la generalidad de la doctrina jurídico-penal, la ignorancia normativa excusable impide afirmar el juicio de culpabilidad. En este sentido, véase Moore (1993: 239-244).

16. Para una breve reseña sobre las consecuencias que esta situación ha generado, así como a las carencias del diseño normativo-institucional del aparato penitenciario chileno, véase Arriagada y Rochow (2015). 
nales de justicia utilizan para compeler a una persona a cumplir con un deber legal y comportarse de una determinada manera, por ejemplo, cuando un tribunal la decreta frente al desacato de una orden dictada por él mismo. ${ }^{17}$ También se utiliza como una medida disciplinaria administrativa para los miembros de las Fuerzas Armadas, de Orden y Seguridad Pública.

La detención, por su parte, es una figura más amplia que el arresto y se refiere a la privación de libertad ambulatoria que sufre una persona de quien se sospecha que ha cometido un delito. ${ }^{18}$ Para efectos de establecer el ámbito de aplicación de la regla constitucional en comento, es fundamental mantener una interpretación amplia de la idea de detención, de modo de evitar una limitación encubierta al alcance de la norma constitucional mediante la configuración de etiquetas que pueden ocultar la afectación material que el derecho recibe (Horvitz y López, 2003: 363). De ahí que, por ejemplo, la práctica de la «retención» para efectos de identificación debe tratarse como una instancia de detención para efectos de la aplicación de la norma constitucional, en la medida en que la libertad ambulatoria de la persona se vea afectada de manera suficientemente intensa.

De acuerdo con la regulación procesal penal chilena, la detención es una medida cautelar personal que tiene un carácter esencialmente transitorio, ya que ante todo persigue hacer comparecer a una persona frente a un tribunal para que este controle la legalidad de la detención y decida sobre la manera en que debe seguir el procedimiento penal en su contra en caso de que este se iniciara. En general, lo que ocurriría sería que el juez debería decidir en torno a las solicitudes del fiscal o liberar al imputado en caso de que el fiscal o el abogado asistente de fiscal no comparecieran a la audiencia. El fiscal, a su vez, podría solicitar una ampliación de la detención por un máximo de tres días o formalizar una investigación penal en contra del detenido y eventualmente solicitar otras medidas cautelares personales como, por ejemplo, la prisión preventiva o las contempladas en los artículos 155 o 156 bis del Código Procesal Penal.

17. A modo de ejemplo, el artículo 14, inciso 1, de la Ley 14.908 del 14 de octubre de 1962, relativa al abandono de las familias y al pago de pensiones alimenticias, dispone lo siguiente: «Si decretados los alimentos por resolución que cause ejecutoria en favor del cónyuge, de los padres, de los hijos o del adoptado, el alimentante no hubiere cumplido su obligación en la forma pactada u ordenada o hubiere dejado de pagar una o más de las pensiones decretadas, el tribunal que dictó la resolución deberá, a petición de parte o de oficio y sin más trámite, imponer al deudor como medida de apremio, el arresto nocturno entre las veintidós horas de cada día hasta las seis horas del día siguiente, hasta por quince días. El juez podrá repetir esta medida hasta obtener el íntegro pago de la obligación».

18. Sin perjuicio de que existen otras hipótesis de detención como la que se decreta en el contexto de un proceso de extradición, nos concentraremos en la detención en el sentido recién señalado, que corresponde a lo que la doctrina suele denominar como detención imputativa. Al respecto, véase Nogueira (1999: 308 y ss.) y Horvitz y López (2003: 365). 


\section{Tipos de detención}

La detención puede proceder básicamente de tres maneras. En primer lugar, puede ser ejecutada por los funcionarios expresamente facultados por la ley en cumplimiento de una orden judicial de detención. El juez puede dictar dicha orden de detención a solicitud del Ministerio Público o de manera autónoma cuando un imputado no compareciere sin causa justificada a una audiencia judicial a la que hubiere sido legalmente citado, como se especifica en el artículo 127 del Código Procesal Penal, o cuando una persona cometiera algún crimen o simple delito dentro de la sala de su despacho, como se especifica en el artículo 128 del mismo Código.

En segundo lugar, la detención puede ser realizada por cualquier persona en caso de flagrancia y en el caso de agentes policiales la detención por delito flagrante es obligatoria. La situación de flagrancia se encuentra contemplada en la Constitución, pero definida en el Código Procesal Penal, ya que lo único que dice la primera es que podrá ser detenido sin orden de autoridad competente legalmente intimada quien «fuere sorprendido en delito flagrante, con el solo objeto de ser puesto a disposición del juez competente dentro de las veinticuatro horas siguientes». De la regulación constitucional se desprende que la detención deberá ser lo más breve posible y que el plazo de 24 horas es un plazo máximo. De este modo, la legalidad de la detención depende no solo de cumplir con dicho plazo, sino también de no dilatar más de lo necesario la entrega del detenido a la autoridad judicial. Adicionalmente, la legalidad de la detención supone que esta se haya limitado a afectar de manera exclusiva los derechos que la institución autoriza a afectar, de ahí que la detención podría ser declarada ilegal si quienes la realizan maltratan física o síquicamente al detenido, lo que además puede implicar la comisión del delito contemplado en el artículo 150 A o 150 B del Código Penal, dependiendo de si se trata de un funcionario público o de un particular.

La determinación de lo que cuenta como una situación de flagrancia se encuentra en el artículo 130 del Código Procesal Penal, de acuerdo con el cual hay delito flagrante básicamente cuando se sorprende a alguien cometiendo un delito o cuando hay indicios claros de que acaba de cometerlo. Este tipo de detención, en general, procede con respecto a cualquier delito de acción penal pública cuya comisión tenga asociada una pena privativa o restrictiva de libertad, además de ciertos delitos cuya persecución penal requiere instancia particular previa. ${ }^{19}$

En tercer lugar, la detención puede ser ejecutada sin orden judicial y por la policía en casos de personas que tuvieran una orden de detención pendiente, así como en una serie de casos de quebrantamiento de condena o violación de medida cautelar personal que se encuentran detallados en el artículo 129 del Código Procesal Penal.

19. El artículo 129 del Código Procesal Penal establece que sí procede la detención por flagrancia en los delitos previstos en los artículos 361 a 366 quater del Código Penal. 


\section{Procedimiento de detención}

La Constitución establece como condición fundamental de legitimidad de la detención que exista una orden de un funcionario público expresamente facultado por ley y que dicha orden le sea legalmente intimada al detenido. En general, las órdenes de detención deben ser despachadas por un juez con competencia penal y a petición del Ministerio Público, salvo las excepciones mencionadas en la sección anterior. ${ }^{20}$ El Código Procesal Penal eliminó la autoridad para detener que el Código de Procedimiento Penal de 1906 le reconocía a algunos funcionarios públicos, como a los intendentes regionales, gobernadores provinciales y alcaldes. Sin embargo, mantuvo la formulación de la Constitución que no exige que la orden de detención emane de un juez, sino que basta que se trate de un «funcionario público expresamente facultado por ley», posiblemente porque a la fecha seguían vigentes algunas hipótesis de detención no judicial, como las que establecía el artículo 13 de la Ley 18.314 de 1984, artículo que fue derogado el año 2002. ${ }^{21}$

La orden de detención debe ser ejecutada por la Policía de Investigaciones o por Carabineros de Chile, de acuerdo con lo dispuesto por el artículo 79 del Código Procesal Penal. Al momento de la ejecución o cumplimiento de la orden, esta debe ser legalmente intimada al detenido, lo que exige comunicarle el fundamento legal y los fundamentos de hecho de la orden de detención dictada en su contra, así como exhibirle la misma. ${ }^{22}$

Adicionalmente, el artículo 135 del Código Procesal Penal exige que al momento de la detención, la persona sea informada de los derechos específicos de los que goza en su calidad de detenida, de modo que la exigencia constitucional de que la orden sea intimada en forma legal implícitamente supone que además de la exhibición y relación de los contenidos de la orden de detención, se cumpla con las formalidades establecidas por la ley, como ocurre con la obligación de informar a la persona detenida de sus derechos. ${ }^{23}$

De acuerdo con el artículo 131 del Código Procesal Penal, luego de intimarse la orden de detención e informar al detenido sobre sus derechos, las policías deberán conducir «inmediatamente al detenido a presencia del juez que hubiere expedido la

20. Básicamente, cuando un imputado no compareciere sin causa justificada a una audiencia judicial a la que hubiere sido legalmente citado según el artículo 127 del Código Procesal Penal, o cuando una persona cometiera algún crimen o simple delito dentro de la sala de despacho del juez según el artículo 128 del Código Procesal Penal.

21. Para más información, véase la Ley 19.806 de 2002.

22. El derecho a que la orden le sea exhibida emana tanto de la Constitución en los literales c) y d) del numeral 7 del artículo 19, así como del artículo 94 del Código Procesal Penal.

23. Para más información, véase el artículo 93, letra g), y el artículo 94 del Código Procesal Penal. 
orden» solo cuando esto no fuera posible y el sujeto podrá permanecer detenido antes de ver al juez por un plazo máximo de veinticuatro horas. Es importante destacar que la regulación legal es más restrictiva que la regulación constitucional, que permite dilatar la comparecencia ante el juez hasta por cuarenta y ocho horas en casos de detenciones practicadas en cumplimiento de una orden de detención emanada de funcionario competente.

A diferencia de lo que ocurre con la detención que ha sido ordenada por funcionario expresamente facultado por ley, la detención por flagrancia precisamente tiene como objetivo establecer una excepción a la exigencia de que la detención solo procede cuando tiene como antecedente una orden de detención que haya sido legalmente intimada. Esto no obsta a que la persona detenida tenga derecho a que se le informen sus derechos, en la medida en que durante la detención interviniera un funcionario sobre el cual pese el deber de informar de acuerdo con lo establecido en el artículo 135 del Código Procesal Penal.

En términos de la duración de la detención por flagrancia, la Constitución Política de la República establece un plazo de veinticuatro horas para que la persona sea puesta a disposición del juez competente. La ley es, nuevamente, parcialmente más restrictiva que la Constitución Política de la República toda vez que, en el caso de detención por delito flagrante, el artículo 131 del Código Procesal Penal obliga a los funcionarios policiales que la hubieran practicado o que tuvieran al detenido bajo su custodia a que informen de esto al Ministerio Público en un plazo de doce horas. En todo caso, el plazo que puede concurrir entre la detención por flagrancia y la comparecencia ante el juez sigue siendo de veinticuatro horas.

Como se señaló anteriormente, este plazo difiere del establecido por la Constitución Política de la República para el caso de la detención efectuada en complimiento de una orden emanada de funcionario legalmente autorizado, que se extiende a cuarenta y ocho horas. Además, la Constitución Política de la República permite al juez dilatar la comparecencia del detenido mediante resolución fundada por un plazo máximo de cinco y diez días en caso de tratarse de hechos legalmente calificados como conductas terroristas.

Un último límite para la detención es un límite subjetivo que dice relación con ciertas categorías de personas que no pueden ser detenidas, ya que gozan de inmunidad jurisdiccional, como ocurre esencialmente en el caso de las misiones diplomáticas. ${ }^{24}$ También existen limitaciones para la detención de los jueces de los tribunales

24. Así, en el artículo 29 del Convenio de Viena sobre Relaciones Diplomáticas de 1961, se establece que los agentes diplomáticos no pueden ser detenidos. Por otra parte, y de acuerdo con lo dispuesto por la Convención de Viena sobre Relaciones Consulares de 1967, existen ciertas personas, como los funcionarios consulares extranjeros, que pueden ser detenidos siempre que se cumplan ciertos requisitos adicionales, como que se trate de un delito grave y que medie autorización judicial. 
de justicia y de los parlamentarios de la República, quienes gozan de una inmunidad relativa. ${ }^{25}$

\section{Detenciones ilegales y recurso de amparo}

Para controlar la legalidad de la detención, imponer sanciones o subsanar los problemas de legalidad que esta pueda haber sufrido, existen fundamentalmente tres instituciones jurídicas: la audiencia de control de la detención (artículo 132 del Código Procesal Penal), el amparo ante el juez de garantía (artículo 95 del Código Procesal Penal) y el recurso de amparo constitucional (artículo 21 de la Constitución Política de la República).

En el contexto del procedimiento penal, los principales efectos que puede producir la ilegalidad de una detención son la nulidad procesal (artículos 159 y 160 del Código Procesal Penal) y la posibilidad de invalidar pruebas para el juicio oral (artículo 276 del Código Procesal Penal) que se hubieran obtenido en el contexto de una detención ilegal. ${ }^{26}$

El derecho al control jurisdiccional de las detenciones o cualquier forma de privación de la libertad personal está además consagrado en el artículo 9 del Pacto Internacional de Derechos Civiles y Políticos, y en el artículo 7 de la Convención Americana de Derechos Humanos. En nuestra Constitución este derecho se ve materializado, además de los controles que puede ejercer el juez de garantía, por la regulación del recurso de amparo constitucional, que es precisamente una acción jurisdiccional que tiene como fin poner término a cualquier privación de libertad ilícita o subsanar los defectos de licitud que esta pudiera tener. La formulación de este recurso es bastante amplia toda vez que ordena el control del tribunal de alzada competente con respecto a cualquier amenaza, perturbación o privación que pudiera ser arbitraria o ilegal (artículo 21 de la Constitución Política de la República).

\section{Retenciones y control de identidad}

El concepto de retención policial ha sido utilizado para referirse a un modo de restricción de la libertad personal, que se encuentra en el límite mínimo del espectro de afectación a la libertad personal que la ley autoriza a las fuerzas de orden y seguridad. Aun cuando no es un concepto legal, la doctrina lo ha formulado para facilitar su distinción de la detención. Sin embargo, como se señaló más arriba, y a pesar de que sea cierto que la retención policial se encuentra en el umbral inferior del espectro

\footnotetext{
25. Para más información, véase el artículo 61 de la Constitución Política de la República y los artículos 416 a 422 del Código Procesal Penal.

26. Para un análisis más acabado de los efectos de la ilegalidad de una detención en un procedimiento penal, véase Arias (2002).
} 
de afectaciones a la libertad personal, debe ser en todo caso comprendida como una forma de detención para efectos de aplicar las normas del artículo 19, número 7 , impidiendo que un fraude de etiquetas configure un espacio excesivo de discrecionalidad que amenace la vigencia de la libertad personal y la seguridad individual.

El caso emblemático de retención policial que ha gozado de una cierta inmunidad frente a la protección constitucional y legal de la libertad personal, es la detención o retención policial que se realiza para efectos de identificación y registro. La evolución de la regulación de esta institución en nuestro sistema procesal penal da cuenta de una tendencia a ampliar las facultades de la policía en desmedro de la seguridad individual y de la certeza de que uno no será afectado ni controlado en su libre desplazamiento por el territorio nacional.

El control de identidad se encuentra regulado en el artículo 85 del Código Procesal Penal y es el heredero del artículo 260 del Código de Procedimiento Penal que regulaba la institución cándidamente denominada "control por sospecha», que fue duramente criticada por configurar un espacio que le permitía a las policías abusar de su poder y restringir de manera arbitraria e impermisible el derecho a la libertad personal. ${ }^{27}$ Entonces, el artículo 85 del Código Procesal Penal intentó consagrar una formulación de este tipo de control preventivo que no abriera la puerta para abusos policiales y que impidiera una restricción ilegítima de la libertad personal y la seguridad individual. Sin embargo, su evolución ha propiciado precisamente lo contrario.

En términos breves, las facultades policiales para controlar la identidad de las personas estaban inicialmente restringidas a la posibilidad de solicitar la identificación a cualquier persona en casos fundados, donde por fundados se consideraban la existencia de un indicio de que la persona hubiera cometido o intentado cometer un crimen, simple delito, o que pudiere contribuir a la indagación sobre la realización de un crimen o simple delito. Cuando la persona se negase o no pudiera identificarse en el lugar, las policías estaban autorizadas para conducirla a la unidad policial más cercana para identificarla. En total, el procedimiento no podía extenderse por más de cuatro horas.

La regulación actual, en cambio, ha ampliado las facultades policiales de manera bastante drástica. Así, el control de identidad dejó de ser una facultad para pasar a ser un deber, y se ampliaron las circunstancias de procedencia incorporando un indicio de que la persona ha cometido una falta y no solamente un crimen o simple delito, así como la facultad de controlar la identidad de quien «se encapuche o emboce para ocultar, disimular o dificultar su identidad» y de quien «los funcionarios policiales tengan algún antecedente que les permita inferir que una persona determinada tiene una orden de detención pendiente».

Además, y de manera bastante crucial, se otorgaron facultades a las policías para

27. En este sentido, véase González y Riego (1994). 
realizar, sin necesidad de un nuevo indicio, un registro de las vestimentas, equipaje o vehículo de la persona, pudiendo detenerla si en el contexto de dicho registro apareciera que la persona se encuentra en situación de flagrancia con respecto a la comisión de un delito.

En relación con la duración de este procedimiento, esta se duplicó, pasando de un plazo de cuatro horas a uno de ocho. No bastando con estas nuevas facultades, se estableció que habiéndose cumplido el plazo de las ocho horas, las policías podrían en todo caso decretar la detención de la persona como autora de la falta prevista en el numeral 5 del artículo 496 del Código Penal cuando existieran indicios de que la persona ha ocultado su identidad o ha proporcionado una falsa. Estableciendo con ello una excepción expresa a la regla de acuerdo con la cual la detención por flagrancia no procede respecto a faltas. ${ }^{28}$

Finalmente, cabe destacar que en la actual regulación se establece que una vez practicada la detención antes referida las policías deberán informarlo inmediatamente al fiscal y la persona detenida deberá ser puesta a disposición del tribunal en un plazo máximo de veinticuatro horas «contado desde que la detención se ha practicado». Dado que la norma constitucional establece un plazo máximo de comparecencia ante el juez de veinticuatro horas para la detención por delito flagrante, y que desde el inicio del control de la identidad la persona se ha visto privada de su libertad ambulatoria en términos absolutos, no cabe sino entender que dicho plazo debería contarse desde el inicio del procedimiento de control de identidad y no luego de vencidas las primeras ocho horas, en caso de que las policías procedieran a la detención por la falta del numeral 5 del artículo 496 del Código Penal. En suma, la frase «contado desde que la detención se ha practicado» debe entenderse en el sentido amplio de detención como cualquier acción que priva o impide a una persona ejercer su derecho de libertad ambulatoria.

El problema frente a facultades policiales de esta naturaleza ha sido denunciado tanto en Chile como en muchos otros países, por configurar un espacio de discrecionalidad que es poco controlado y suele utilizarse de manera excesiva por la policía sobre grupos socialmente desfavorecidos. Esto implica que ciertos grupos ven amenazadas de manera más intensa que otros las condiciones de su seguridad individual y la confianza que pueden tener en los agentes del Estado. Esto profundiza el carácter sesgado o desigual del control penal y fortalece los estereotipos sociales que propician la mantención de las desigualdades materiales, así como una preocupante desigualdad formal ante la ley. ${ }^{29}$

28. En este sentido, véase lo dispuesto en los artículos 124 y 134 del Código Procesal Penal, donde se incluye esta falta como una de las excepciones en que sí procede la detención por flagrancia en caso de faltas.

29. Para un análisis crítico, véase Irarrázabal (2015). 


\section{Lugar de detención}

La letra d) del artículo 19, número 7, establece que los únicos lugares en los que una persona puede ser privada de su libertad ambulatoria para efectos de cumplir con una medida de arresto, detención, prisión preventiva o prisión, es en la casa de la misma persona o en un lugar público que se haya destinado a este objeto. En nuestro ordenamiento, en general estos lugares corresponden a los establecimientos penitenciarios administrados por el Servicio de Gendarmería de Chile, que depende del Ministerio de Justicia, y se clasifican en Centros de Detención Preventiva, Centros de Cumplimiento Penitenciario, Centros Penitenciarios Femeninos, Centros de Educación y Trabajo, Centros Abiertos, Centros Agrícolas, Centros de Reinserción Social y Complejos Penitenciarios. ${ }^{30}$

A continuación, el literal d) establece una serie de condiciones que deben cumplirse en el lugar de detención, que atienden fundamentalmente a proteger la seguridad individual del individuo, exigiendo que los encargados de dichos establecimientos mantengan un registro rigurosamente actualizado y público de la identidad de las personas que se encuentran detenidas en cada establecimiento y la orden de autoridad legalmente facultada que impuso la privación de libertad.

Adicionalmente, la norma constitucional prohíbe imponer formas de incomunicación a las personas detenidas que impidan a los funcionarios de dichos establecimientos visitar a las personas que se encuentren privadas de libertad en ellos. Además, la norma constitucional obliga a los funcionarios de estos establecimientos a transmitir la orden de detención al juez competente o requerir una copia de la misma, así como a otorgar un certificado de que la persona se encuentra recluida en el establecimiento que administra. La finalidad de estas exigencias es ante todo impedir que las personas que se encuentren en dichos establecimientos sean sometidos a formas de trato arbitrarias y carezcan de acceso a las instituciones que aseguran y controlan la legalidad de los actos de la administración del Estado, mediante el establecimiento de un sistema de rigurosa transparencia y publicidad que asegure un nivel mínimo de acceso a la justicia por parte de las personas que se encuentran recluidas en dichos establecimientos.

La regulación constitucional de los establecimientos penitenciarios debe complementarse con las reglas establecidas a este respecto por los pactos internacionales de derechos humanos que son vinculantes para Chile. En este contexto, es imprescindible comentar algunas de ellas. En primer lugar, el artículo 10 del Pacto Internacional de Derechos Civiles y Políticos establece que las personas privadas de libertad deben ser tratadas «con el respeto debido a la dignidad inherente al ser humano» y exige

30. Una descripción de cada uno de estos tipos de establecimientos penitenciarios se encuentra en el título I del Reglamento de Establecimientos Penitenciarios, Decreto Supremo 518 de 1998. 
que los establecimientos penitenciarios separen a la población procesada de la condenada, y las someta a un trato diferenciado que sea consistente con la presunción de inocencia de la que gozan las personas procesadas. Esta norma ha sido replicada en el artículo 5 de la Convención Americana de Derechos Humanos y en el Reglamento de Establecimientos Penitenciarios. ${ }^{31}$

De manera similar, el artículo 10 del Pacto Internacional de Derechos Civiles y Políticos, el artículo 5 de la Convención Americana de Derechos Humanos (reflejado en el artículo 18 del Reglamento de Establecimientos Penitenciarios), y el artículo 37 de la Convención sobre los Derechos del Niño, obligan a que los establecimientos penitenciarios o cualquier centro de detención mantenga separada a la población adulta de los menores de edad, a menos que el interés superior del niño demande lo contrario.

\section{Prisión preventiva}

La letra e) del artículo 19, número 7, de la Constitución Política de la República establece los límites de procedencia de la prisión preventiva, es decir, la prisión que se puede decretar como medida cautelar de un procedimiento penal antes de que se dicte sentencia condenatoria. La regla constitucional es básicamente la prohibición de imponer la prisión preventiva a menos que concurran ciertas condiciones: i) que el juez la considere como necesaria para las investigaciones; ii) que el juez la considere como necesaria para la seguridad del ofendido; o iii) que el juez la considere como necesaria para la seguridad de la sociedad. Una regla similar puede encontrarse en el artículo 9 del Pacto Internacional de Derechos Civiles y Políticos, y en el artículo 7 de la Convención Americana de Derechos Humanos, salvo en lo que respecta a las condiciones de procedencia de la prisión preventiva. ${ }^{32}$

El fundamento de la excepcionalidad de la prisión preventiva está dado por la presunción de inocencia, que exige que mientras no exista una sentencia condenatoria y se haya probado la culpabilidad del acusado más allá de toda duda razonable, este sea tratado como inocente. En términos estrictos, sin embargo, la presunción de inocencia debería conducir a eliminar la prisión preventiva toda vez que esta consiste, en los hechos, en una privación de libertad completamente equivalente en términos materiales a la pena privativa de libertad que se podría imponer al acusado de probarse su responsabilidad penal. Uno podría pensar que la presunción de inocencia

31. Para más información, véase el artículo 14 del Decreto Supremo 518 de 1998.

32. Como se comentará más adelante, estas reglas internacionales sostienen que las únicas razones legítimas para imponer la prisión preventiva son asegurar la comparecencia del imputado al juicio y garantizar la ejecución de la sentencia. De este modo, se descartan las consideraciones sobre la seguridad del ofendido y de la sociedad. 
es compatible con la prisión preventiva en la medida que esta última tuviera fines claramente diferenciables de una pena. Sin embargo, esto no es fácil de sostener en nuestro ordenamiento jurídico de cara a las circunstancias que autorizan la precedencia de esta medida cautelar. ${ }^{33}$

La tensión entre la presunción de inocencia y la prisión preventiva es resuelta de diversas maneras en los ordenamientos jurídicos en la medida que cambian los principios y valoraciones que informan sus reglas. Así, durante la vigencia del Código de Procedimiento Penal en Chile, la prisión preventiva era una consecuencia automática del auto de procesamiento de modo que durante el procedimiento y antes de que se demostrara la culpabilidad del imputado, la regla general era la prisión preventiva y la libertad era la excepción, de ahí que se le denominara libertad provisional. ${ }^{34} \mathrm{La}$ Constitución Política de la República por su parte, hasta el año 2005, también se refería a la libertad provisional del imputado, correspondiéndose de este modo con las valoraciones del antiguo sistema inquisitivo en el cual la presunción de inocencia tenía una presencia institucional prácticamente inexistente.

A partir de la Ley de Reforma Constitucional 20.050, la Constitución Política de la República modificó su formulación del literal e) del artículo 19, número 7, quedando en armonía con las valoraciones que impuso la reforma procesal penal en este contexto al establecer un claro compromiso con los derechos del imputado y en particular con su presunción de inocencia. Esto, además permitió que la Constitución Política de la República armonizara sus disposiciones con lo establecido en el artículo 9 del Pacto Internacional de Derechos Civiles y Políticos, y el artículo 7 de la Convención Americana de Derechos Humanos. Sin embargo, podría sostenerse que esta armonización no ha sido absoluta toda vez que los estándares de derecho internacional parecen exigir que la prisión preventiva solo se imponga para asegurar la comparecencia del imputado a las actuaciones procesales y la ejecución del fallo, y no para otros fines como los que reconocen nuestra Constitución y el Código Procesal Penal. ${ }^{35}$ Adicionalmente, luego de la modificación que sufrió el artículo 149 del Código Procesal Penal en 2008, al que se le agregó un inciso segundo que dispone que tratándose de ciertos delitos la resolución que niega o revoca la prisión preventiva no tendrá efecto hasta que se encuentre firme, la presunción de inocencia se ha visto aún más limitada. Esto es así porque la citada regla implica que aun cuando un juez ordene la libertad de una persona denegando o renovando su prisión preventiva, esta debe ser en todo caso detenida hasta que la apelación a dicha decisión sea conocida y fallada. ${ }^{36}$

33. En este sentido, véase Horvitz y López (2003: 389-392).

34. Para más información, véase los artículos 276, 277 y 356 del Código de Procedimiento Penal.

35. Para más información, véase el artículo 140 del Código Procesal Penal.

36. Sobre este último problema, véase Ferrada (2009). 


\section{Garantía de no autoinculpación o inculpación de familiares}

En nuestro ordenamiento jurídico, como en la mayoría de los ordenamientos occidentales, existe un derecho a no declarar contra uno mismo o contra algunos familiares. De acuerdo con lo establecido en el literal f) del artículo 19, número 7:

En las causas criminales no se podrá obligar al imputado o acusado a que declare bajo juramento sobre hecho propio; tampoco podrán ser obligados a declarar en contra de este sus ascendientes, descendientes, cónyuge y demás personas que, según los casos y circunstancias, señale la ley.

Una norma similar puede encontrarse en el artículo 14 del Pacto Internacional de Derechos Civiles y Políticos, en el artículo 8 de la Convención Americana de Derechos Humanos, y en el artículo 93 del Código Procesal Penal. También es posible construir una vinculación entre esta norma y algunas normas penales como la que exime de las penas por encubrimiento a quienes realizan las conductas descritas en el artículo 17 del Código Penal con respecto a delitos cometidos por su cónyuge o parientes.

Existen diversos tipos de racionalidades para justificar la existencia de la regla que le permite a una persona no declarar contra sí misma, las que nos podrían ayudar a iluminar en qué consiste este derecho y cuál es su alcance. En primer lugar, uno podría pensar que la norma se justifica para proteger los fines del proceso penal. Asumiendo que a pesar de su violencia el derecho penal fuera una forma válida de organizar ciertos aspectos de la interacción social (algo que no es para nada obvio), el derecho procesal penal buscaría asegurar que exista un proceso que logre establecer la efectividad de las condiciones para el juicio de responsabilidad penal individual, minimizando las posibilidades de error en dicho juicio, en particular, las posibilidades de condenar a un inocente. Dada la asimetría de poder entre el Estado y los individuos, el proceso penal debe diseñarse de modo de evitar todos los posibles abusos que el Estado pueda cometer atendida su posición privilegiada, de ahí que no bastaría con asegurar que solo se castigue a los culpables, sino que además el procedimiento debe ser consistente con la idea de que quien es juzgado es un ciudadano que debe ser tratado con respeto. Desde el punto de vista de estos fines del proceso penal, entonces, el derecho a no declarar contra uno mismo aparecería como un límite a la función investigativa que contribuiría a asegurar que no se castigue a los inocentes y que el procedimiento no sea autoritario o abusivo, por ejemplo, mediante la imposición de declaraciones forzadas.

Además, el derecho a no declarar contra uno mismo puede servir para la detección de los culpables en la medida que facilita la declaración de testigos (toda vez que estos no tendrían miedo a arriesgar una persecución penal en su contra al declarar) y contribuiría al desarrollo tanto de medios de investigación como de prueba más 
sofisticados que mejorarían tanto la labor investigativa de las policías como del ministerio público. Para asegurar esta función, sin embargo, no es necesario reconocer un derecho general a la no autoincriminación, entendido como un derecho a no contribuir en modo alguno con la propia condena, sino que bastaría con un derecho a no declarar contra uno mismo.

En segundo lugar, la existencia de un derecho a la no autoincriminación materializaría el principio de presunción de inocencia en la medida en que este se expresa en la idea de que la carga de la prueba sobre la culpabilidad de un individuo descansa en quien lo acusa. El derecho a no declarar contra uno mismo contribuiría a que el Estado mantuviera dicha carga de probar la responsabilidad penal del acusado, toda vez que la declaración que pudiera aportar el imputado no podría ser el fundamento exclusivo de una condena penal y eso obligaría al órgano persecutor a cumplir con su rol probatorio. No obstante, la presunción de inocencia no es más que una regla que otorga un criterio de decisión con respecto a quién tiene responsabilidad de acreditar los hechos y de cómo deben valorarse las pruebas en términos de la certeza que deben proporcionar y, más allá de las consideraciones anteriores, de la presunción de inocencia no parece desprenderse una razón por la cual el imputado no puede contribuir de modo alguno a su propia condena.

En tercer lugar, el fundamento de esta prohibición puede encontrarse en la necesidad de prevenir la tortura y la coacción como medios de obtención de pruebas. Ciertamente, existen reglas que limitan la manera en que el fiscal puede producir pruebas y entre ellas se encuentra la prohibición de la utilización de medios coactivos para la obtención de declaraciones o pruebas, según lo dispone el artículo 195 del Código Procesal Penal. En este contexto, la existencia del derecho a guardar silencio aseguraría o contribuiría a eliminar prácticas de violencia o abuso que puedan generarse en el contexto de una investigación criminal.

Finalmente, el fundamento de la prohibición de prestar declaración puede encontrarse en la dignidad del imputado en el sentido de que buscaría evitar la alienación a la que podría conducir un deber que se dirige contra un instinto básico de autoprotección. De acuerdo con estas ideas, sería inhumano forzar a un individuo a dañarse a sí mismo, aun cuando la imposición de ese mismo daño de la mano de un tercero fuera permisible. ${ }^{37}$ Históricamente, de hecho, parece que el derecho a guardar silencio se instituyó como una forma de evitar la crueldad en el contexto del proceso penal. En la tradición anglosajona, el origen de esta institución se ha rastreado al denominado juramento ex officio que ponía al imputado en una opción cruel: el sujeto

37. En un ejemplo formulado por David Dolinko, un asesino que obliga a una madre a elegir a cuál de sus hijos matará es doblemente cruel frente a un asesino que simplemente mata a uno de ellos. De esto se seguiría que a pesar de que castigar a alguien no es cruel, sí sería cruel obligar a alguien a contribuir en la imposición de su propio castigo. Para más detalles, véase Dolinko (1985: 1102-1104). 
arriesgaba ser autor de perjurio si mentía, una pena si se quedaba en silencio o autoincriminarse si declaraba la verdad. Algo similar ocurriría actualmente de no existir esta norma en la medida en que un sujeto se podría ver enfrentado a la disyuntiva de cometer un delito de perjurio o asegurar su propia condena.

En nuestro ordenamiento jurídico no existe un principio general en virtud del cual se encuentre prohibido que una persona facilite en modo alguno su propia condena penal. La existencia del procedimiento abreviado y la facilidad con la que se celebra en nuestro quehacer penal da cuenta de cómo, en la práctica, aun cuando la declaración del imputado no es la fuente de su condena, este facilita en los hechos, mediante su declaración de aceptación de los hechos invocados en la acusación fiscal, que se dicte una sentencia condenatoria en su contra. Si nuestro ordenamiento jurídico tuviera un compromiso con un principio que prohibiera toda forma de autoincriminación, el procedimiento abreviado o el procedimiento simplificado derechamente no deberían existir.

Sin embargo, de lo anterior tampoco se sigue que la interpretación del derecho a no autoincriminarse deba hacerse de manera restrictiva o formal, limitándola a la prohibición de obligar al acusado a prestar declaración bajo juramento en un procedimiento penal. En efecto, su consagración constitucional podría dar cuenta de que se trata de un derecho más general a no verse obligado a generar pruebas incriminatorias contra uno mismo. ${ }^{38}$ Sin embargo, el Tribunal Constitucional ha interpretado la norma de una manera más bien restrictiva, limitando la eficacia de dicho derecho a las declaraciones que se producen en el contexto de un juicio penal. ${ }^{39}$

\section{Prohibición de la confiscación de bienes y de privación de derechos previsionales}

Los literales g) y h) del artículo 19, número 7, prohíben ciertas formas de sanción punitiva como la confiscación de bienes o la pérdida de derechos previsionales, las que vienen a sumarse a la tímida restricción al establecimiento de la pena de muerte, consagrada en el artículo 19, número 1. Estas normas tienen como objeto resguardar tanto la humanidad como la personalidad de las penas, es decir, evitar que las penas supongan un tipo de interacción que afecte o cancele lo que configura la dignidad de

38. Para más información, véase el voto de minoría en la causa del Tribunal Constitucional, rol 28972015 INA, del 4 de julio de 2017.

39. Para más información, véase la sentencia del Tribunal Constitucional, rol 2897-2015 INA, del 4 de julio de 2017. Este pronunciamiento se produjo a propósito de la norma que tipifica y sanciona penalmente la omisión de dar cuenta a la autoridad de un accidente de tránsito en el que se ha participado y donde se ha producido la muerte o lesiones de un tercero (artículo 195 de la Ley de Tránsito). En relación con la legitimidad de la punibilidad de la negativa a someterse a test toxicológicos, véase Valenzuela (2015) y Falcone (2015). 
una persona de acuerdo con las valoraciones de nuestra sociedad, así como evitar que tenga efectos con respecto a personas que no realizaron el delito, como podría ocurrir, por ejemplo, con el grupo familiar del condenado en caso de una pena de confiscación de bienes o de privación de derechos previsionales (Nogueira, 1999: 329). El principio de personalidad de las penas ha sido consagrado explícitamente en el artículo 5 de la Convención Americana de Derechos Humanos.

La confiscación consiste en desposeer de bienes de su propiedad a la persona condenada por un delito, una sanción que como señala el literal g) solo será constitucional en el caso de asociaciones ilícitas. Dado el sentido que tiene la disposición, es decir, evitar que la pena afecte a personas no responsables por el delito, en el caso de asociaciones ilícitas esta sanción solo debería recaer sobre los bienes de la asociación (Cury, 1992: 373). Adicionalmente, la norma constitucional autoriza otra hipótesis de confiscación, esto es el comiso, en los casos establecidos por la ley. De acuerdo con el artículo 31 del Código Penal, el comiso, es decir, la privación de los bienes que provengan de la comisión del delito y los instrumentos con los que este fue ejecutado, procede en general como pena accesoria a toda pena por crimen o simple delito. En relación con las faltas, este podría ser decretado a discrecionalidad del tribunal de acuerdo con lo establecido en el artículo 500 del Código Penal. El dinero y los bienes decomisados liquidados deberán recibir el mismo destino que recibe el producto de las multas, de conformidad a lo que establece el artículo 60 del Código Penal.

\section{Indemnización por error judicial}

El último literal del artículo 19, número 7, de la Constitución Política de la República establece el derecho de una persona a ser indemnizada por el Estado cuando hubiese sido sometido a un proceso penal o condenado por una resolución judicial injustificadamente errónea o arbitraria. En nuestro ordenamiento ya se encontraba consagrado este derecho en el artículo 20 de la Constitución de 1925 en los siguientes términos: «Todo individuo en favor de quien se dictare sentencia absolutoria o se sobreseyere definitivamente, tendrá derecho a indemnización, en la forma que determine la ley, por los perjuicios efectivos o meramente morales que hubiere sufrido injustamente».

Presuntamente, la excesiva amplitud del derecho a indemnización contemplado en la Constitución Política de la República de 1925 habría llevado a que el legislador nunca dictara la ley que establecería el procedimiento para ejercer este derecho y que en la práctica no fuera una institución relevante (Garrido Montt, 1999: 478). Entonces, es de suponer que los términos más restrictivos que impuso la Constitución Política de la República vigente buscaron una solución de compromiso que permitiera una institución que operase en la práctica, pero que no fuera demasiado 
amplia en su alcance..$^{40}$ En los hechos, la Corte Suprema ha sido muy restrictiva en su interpretación, contribuyendo a mantener la práctica institucional de que los errores judiciales en materia penal no generan responsabilidad para el Estado, sin perjuicio de lo cual en los últimos años la Corte Suprema parece estar asumiendo una interpretación algo más favorable al derecho a ser indemnizado (Garrido Montt, 1999: 481-482). ${ }^{41}$ A continuación, se revisan brevemente las condiciones para ejercer este derecho y las razones que explicarían que la indemnización haya procedido en tan pocas oportunidades. ${ }^{42}$

Para ejercer este derecho es necesario que una persona haya sido sometida a un proceso penal o haya sido condenada como autor, cómplice o encubridor de un delito, cuasidelito o de una falta. Luego de la condena o del sometimiento a proceso, debe haberse dictado un sobreseimiento definitivo o una sentencia absolutoria a favor de la misma persona. Si estas condiciones se encuentran presentes, es formalmente posible ejercer esta acción contra el Estado, y lo que se discutirá para determinar si procede la indemnización o no, es si acaso la resolución judicial que lo hubiese condenado o sometido a proceso ha sido injustificadamente errónea.

El procedimiento de esta acción tiene dos etapas. La primera, se encuentra regulada en el Auto Acordado de la Corte Suprema del 10 de abril de 1996 que establece el procedimiento que tiene lugar frente a la Corte Suprema para efectos de que esta declare si acaso la resolución que sometió a proceso o condenó al solicitante fue injustificadamente errónea o arbitraria. El solicitante tiene un plazo de seis meses desde que haya quedado firme la sentencia absolutoria o el sobreseimiento definitivo. La segunda etapa solo tiene lugar una vez que la Corte Suprema haya declarado a la resolución judicial impugnada como injustificadamente errónea o arbitraria. Esta consiste en un procedimiento breve y sumario ante el tribunal civil competente para que determine el monto de la indemnización por el error cometido. Durante el procedimiento, el Estado es representado por el Consejo de Defensa del Estado.

Las cuestiones que vale la pena analizar en relación con esta acción son dos. En primer lugar, con respecto a qué resoluciones procede este recurso y, en segundo lugar, en qué consiste el error o la arbitrariedad injustificada a que alude la norma. En relación con lo primero, desde ya debe descartarse la procedencia de este recurso con respecto a resoluciones que hayan afectado la libertad personal, pero que no hayan tenido como objeto condenar a una persona o someterla a proceso. Esto implica que

40. Para más información, véase Zúñiga (2008).

41. Para un análisis de un caso reciente en que la Corte Suprema cambió de rumbo en la interpretación de la regla, véase Libertad y Desarrollo, «Fallos Públicos núm. 59», julio de 2015, disponible en bit. ly/2XloAfw.

42. Para un análisis general y actualizado sobre la responsabilidad del Estado por el error judicial, véase Díaz y Muñoz (2015). 
no procedería esta acción de indemnización por un error judicial que recayese sobre otras formas de afectación judicial a la libertad personal, como una orden de detención o una orden de expulsión del territorio nacional para el caso de los migrantes. No obstante, el aspecto más problemático del tipo de resolución que puede ser impugnado con este recurso tiene que ver con la manera en la que corresponde interpretar la exigencia de una resolución por la cual se haya sometido a proceso a una persona.

Al momento de la promulgación de la Constitución Política de la República, el proceso penal vigente contaba con una resolución judicial claramente reconocible como una resolución a través de la cual una persona era sometida a proceso, esta era la denominada encargatoria de reo. En el actual proceso penal, sin embargo, la etapa procesal equivalente a partir de la cual, por ejemplo, se vuelve posible decretar medidas cautelares es la formalización de la investigación, la que no es propiamente una resolución judicial, como tampoco lo es la acusación. Tanto la formalización de la investigación como la acusación, son acciones procesales del Ministerio Público en las que el órgano jurisdiccional se limita a resguardar su legalidad. En este sentido, pareciera que la única resolución judicial en que se somete a proceso a una persona es el auto de apertura del juicio oral, que en todo caso es una resolución que se dicta excepcionalmente.

Frente a esta dificultad, la jurisprudencia de la Corte Suprema ha variado desde lo que podría considerarse una interpretación excesivamente restrictiva y formalista a una interpretación teleológica que pone la atención en la protección del derecho constitucional a la libertad personal. En efecto, en un fallo de 2008, la Corte Suprema sostuvo que la acción solo procedería con respecto a una sentencia condenatoria dado que no existiría en el sistema procesal actual una resolución equivalente a la que sometía a proceso a una persona como la encargatoria de reo. ${ }^{43}$ Sin embargo, durante el 2014 y el 2015, la misma Corte ha sostenido que dado que el fundamento del derecho consagrado en el literal i) del artículo 19, número 7, es proteger la libertad personal, la exigencia de una resolución que haya sometido a proceso al reclamante debe ser interpretada en términos amplios como una resolución que en los hechos puede implicar las mismas consecuencias nocivas para la libertad que suponía la encargatoria de reo, que son básicamente la imposición de la prisión preventiva u otras medidas cautelares personales. ${ }^{44}$

Lo anterior no puede sino ser correcto en la medida que, en términos sustantivos, no existe razón aparente por la que uno debiera restringir la idea de «sometido a pro-

43. Corte Suprema, rol 3815-2006, del 1 de julio de 2008.

44. Corte Suprema, rol 1579-2015, del 8 de julio de 2015. El fallo hace alusión a las siguientes causas: Corte Suprema, rol 4921-2014, del 9 de junio de 2014; y Corte Suprema, rol 22356-2014, del 20 de abril de 2015. Para un análisis de la Sentencia de la Corte Suprema, rol 1579-2015, véase Libertad y Desarrollo, «Fallos Públicos núm. 59», julio de 2015, disponible en bit.ly/2XloAfw. 
ceso» a la formulación del antiguo Código de Procedimiento Penal, ya que nuestra legislación procesal penal vigente tiene su propia formulación en relación con cuándo se entiende que se ha iniciado el proceso en contra de una persona. En efecto, de acuerdo con el artículo 7 del Código Procesal Penal, uno podría decir que una persona se encuentra sometida a proceso desde «la primera actuación del procedimiento dirigida en su contra».

En relación con el criterio de error o arbitrariedad injustificada, en general se ha sostenido que un error injustificado tiene lugar cuando la sentencia se ha basado en una errada percepción de la realidad y este error es inexcusable o inaceptable. La arbitrariedad injustificada, en cambio, alude a la falta de razón o procedencia normativa de la resolución impugnada, en términos también inexcusables (Garrido Montt, 1999: 477-478). Por su parte, la Corte Suprema ha señalado que:

$77^{\circ}$ Una resolución o sentencia es injustificadamente errónea cuando los razonamientos que la conducen al resultado inexacto no convencen (no son convincentes), cuando no son susceptibles de una explicación razonable (racional) cuando, en fin, son contrarios a la lógica, a los dictados de la experiencia y a los conocimientos más difundidos sobre la materia respecto a la cual versa $[\ldots] 11 .^{\circ}$ Que cabe agregar que de acuerdo con lo expresado por la Comisión Constituyente en la sesión 119, el error judicial debe ser manifiesto, craso, que es el que no admite excusa ni razón para explicarlo y, por su parte, la arbitrariedad corresponde a un acto o proceder contrario a la justicia, la razón o las leyes y dictado por la sola voluntad o el capricho.45

Más allá de las críticas que justificadamente ha recibido la excesiva limitación del alcance de la norma, tanto por su formulación como por la interpretación que ha hecho la Corte Suprema, es importante considerar que, en el contexto del proceso penal, también existe la posibilidad de solicitar reparación por las actuaciones injustificadamente erróneas o arbitrarias del Ministerio Público, de conformidad a lo que dispone el artículo 5 de la Ley Orgánica Constitucional del Ministerio Público, que señala que «el Estado será responsable por las actuaciones injustificadamente erróneas o arbitrarias del Ministerio Público». ${ }^{46}$

\section{Titulares}

La cuestión de quiénes tienen derecho a exigir que se les asegure todo lo que la disposición ordena, es distintivamente relevante en el contexto de esta disposición constitucional toda vez que al regular la libertad ambulatoria la norma hace referencia

45. Corte Suprema, rol 3815-2006, del 1 de julio de 2008.

46. Críticamente, véase Zúñiga (2008) y Garrido (1999). Sobre la distinción entre el régimen de responsabilidad del Estado por resoluciones judiciales y el régimen de responsabilidad por actuaciones del Ministerio Público, véase Vodanovic (2005). 
no solo al desplazamiento interno dentro de las fronteras de Chile, sino también a la libertad para entrar y salir del territorio nacional. Entonces, surge la pregunta sobre el alcance de la disposición para personas que no poseen un estatus legal de residentes, ciudadanos o nacionales de Chile.

De acuerdo con lo discutido más arriba, todo parece indicar que tanto esta como cualquier otra norma que asegure derechos fundamentales otorga una protección universal, lo que implica que son titulares para ejercer este derecho todas las personas que se encuentren en el territorio nacional. De este modo, las disposiciones que establezcan un ejercicio diferenciado del derecho a desplazarse libremente dentro del territorio nacional, así como para ingresar o salir de este, deben estar justificadas en base a razones que no pongan en duda la igualdad de derechos que existe entre todas las personas, sean estas nacionales o extranjeras. ${ }^{47}$

\section{Destinatarios}

Una última cuestión que puede ser de interés para efectos de delinear el contenido y límites de este derecho, es la determinación de los destinatarios de la norma. De lo analizado a lo largo de este artículo se desprende que el principal destinatario de las disposiciones del artículo 19, número 7, son las agencias coactivas del Estado, en particular las Fuerzas de Orden y Seguridad Pública, que de acuerdo con el artículo 101 de la Constitución Política están constituidas por Carabineros e Investigaciones. Estas instituciones poseen autorizaciones constitucionales y legales para restringir o privar a las personas de su libertad personal con el objeto de cumplir con su cometido constitucional, que de conformidad al segundo inciso de la norma recién referida consiste en «dar eficacia al derecho, garantizar el orden público y la seguridad pública interior».

Las restricciones o privaciones de libertad personal que pueden realizar las fuerzas de orden y seguridad pueden ser de dos tipos. En primer lugar, puede tratarse de actuaciones espontáneas o directas, en las que el legislador les otorga la facultad de decidir directamente si corresponde hacer uso de la fuerza para responder frente a una situación que amenaza el orden o la seguridad pública. En segundo lugar, las fuerzas de orden y seguridad pueden actuar en cumplimiento de una orden judicial o administrativa.

En adición a las Fuerzas de Orden y Seguridad Pública, debe mencionarse a las Fuerzas Armadas, quienes a diferencia de las primeras en general carecen de potestades para actuar de manera espontánea o directa en la restricción de la libertad personal, a excepción de las facultades especiales que se les pueden otorgar en el contexto de un estado de excepción constitucional.

47. Sobre el particular, véase Galdámez (2014). 
Como parte de las agencias coactivas del Estado, se encuentra también el Servicio de Gendarmería de Chile, constituido en el Decreto Ley 2.859 de 1979 y que tiene como misión dirigir los establecimientos penitenciarios del país vigilando el cumplimiento de las medidas restrictivas y privativas de libertad impuestas por el órgano jurisdiccional, así como atender y asistir a las personas que se encuentran bajo su vigilancia y propiciar su reinserción social. En el cumplimiento de estas misiones, Gendarmería de Chile tiene facultades directas para restringir la libertad personal de los internos que van más allá de lo establecido en la orden judicial de internamiento, ya que es parte de un poder disciplinario que la ley le ha atribuido directamente a esta institución. ${ }^{48}$

Más allá de las agencias recién mencionadas, el principal destinatario de la regulación constitucional de la libertad personal y la seguridad individual es la institución sobre la cual descansa la protección de este derecho en definitiva, es decir, el poder judicial. Un deber que se materializa en términos simbólicos en la acción de amparo regulada por el artículo 21 de la Constitución Política de la República, popularmente conocida como la acción de habeas corpus. En efecto, un aspecto esencial de la función de los tribunales de justicia en el contexto de un Estado democrático es velar por que las agencias coactivas del Estado no se sobrepasen en sus atribuciones y ejerzan su poder de manera criteriosa y adecuada a derecho.

Esta expectativa de que el Poder Judicial ejerza este rol de aseguramiento sobre este derecho ha sido, de hecho, una de las capacidades que le permitieron trascender su rol de emisario del soberano para constituirse en un poder autónomo de un Estado de derecho que tiene una función de control con respecto a las acciones de las otras instituciones políticas. ${ }^{49}$ Un correcto ejercicio de este poder permite distinguir un Poder Judicial que se comporta como una institución fundacional y emblemática de un Estado democrático de derecho o como un mero aparato burocrático para facilitar el gobierno de quien detente del Poder Ejecutivo, como suele ocurrir en sistemas políticos totalitarios o absolutistas. La cuestión no puede quedar mejor evidenciada por el destino que suelen tener los recursos de amparo o acciones de habeas corpus durante las dictaduras u otras formas de tiranía. ${ }^{50}$

Finalmente, cabe comentar en torno a la manera en la que la norma se dirige a las personas naturales. Más allá de la cuestión teórica sobre si acaso las normas de derechos fundamentales tienen eficacia horizontal o no, en el caso de la libertad personal el problema está bastante resuelto en términos prácticos dada la expansiva regulación penal que recibe la protección de la libertad personal, así como la seguridad individual. En este sentido, hay una gran cantidad de delitos que establecen normas

48. Para más información, véase el artículo 81 del Decreto Supremo 518 de 1998.

49. Para más información, véase Galanter (1969).

50. Un estudio sobre el caso chileno puede encontrarse en Hilbink (2007). 
de conducta tendientes a impedir la afectación de estos derechos por parte de otros particulares $y$, aunque en muchos casos estos no se encuentran sistematizados como ataques a la libertad personal, pueden ser fácilmente reconocidos así.

En su dimensión más genérica, la afectación de la libertad personal como ejercicio de autonomía se encuentra prohibida en el Código Penal en los términos del tipo de coacciones violentas del artículo 494, número 16, y del delito de amenazas condicionales establecido en los artículos 296, número 1, número 2, y 297, todos del Código Penal. En su dimensión de libertad ambulatoria, el Código Penal prohíbe la privación de libertad en los artículos 141 y 143 al sancionar las conductas que comúnmente se conocen como secuestro o como detención irregular o ilegítima respectivamente. ${ }^{51}$

En adición a estas normas, el Código Penal establece una serie de tipos penales que podrían considerarse como atentados contra la libertad personal en su dimensión de autonomía o derechamente como una afectación a la seguridad individual como, por ejemplo, el delito de sustracción de menores regulado en el artículo 142 y el delito de inducción al abandono del hogar del artículo 357.

\section{Referencias}

ARIAS, Cristián (2002). «El control jurisdiccional de la detención». Revista de Estudios de la Justicia, 6: 225-253. Disponible en bit.ly/3gebytg.

Arriagada, Isabel y Diego Rochow (2015). «Privación de libertad en Chile: desgobierno carcelario y afectación de derechos de la población penal». En Informe Anual sobre Derechos Humanos en Chile 2015 (pp. 161-207). Santiago: Universidad Diego Portales.

BAssa, Jaime y Fernanda Torres (2015). «Desafíos para el ordenamiento jurídico chileno ante el crecimiento sostenido de los flujos migratorios». Estudios Constitucionales, 13 (2): 103-124. Disponible en bit.ly/2zmrV96.

BERLIN, Isaiah (1986). «Two concepts of liberty». En Robert Stewart (editor), Readings in Social and Political Philosophy (pp. 295-324). Nueva York: Oxford University Press.

Casgrain, Antoine y Michael Janoschka (2013). «Gentrificación y resistencia en las ciudades latinoamericanas: El ejemplo de Santiago de Chile». Andamios, 10 (22): 19-44. Disponible en bit.ly/3cWb6QZ.

Cazor, Kamel y Emilio Pfeffer (2009). «La búsqueda de criterios orientadores en la configuración de las potes- tades normativas en Chile». Revista Ius et Praxis, 15 (1): 191-227. DOI: 10.4067/So718-00122009000100006.

CoHen, Gerald (2008). «Freedom and money». En Laurence Thomas (editor), Contemporary Debates in Social Philosophy (pp. 19-42). Estados Unidos: Blackwell Publishing.

51. Para más información, véase a Etcheberry (1997) y Garrido Montt (2010: 401). 
Cordelli, Chiara (2015). «Justice as Fairness and Relational Resources». Journal of Political Philosophy, 23 (1): 86-110. Disponible en bit.ly/36mz19G.

Cordero Eduardo (2009). «El SENTIDO aCtUAL Del Dominio Legal y la POTEStad reglamentaria». Revista de Dere- Cho de la Pontificia Universidad Católica de VALPARAÍso, 32: 409-440. DOI: 10.4067/So718-68512009000100012. Cury, Enrique (1992). Derecho penal. Parte general. Tomo II. Santiago: Jurídica de Chile.

DíAz, Natalia y Pamela Muñoz (2015). «La responsabilidad del Estado-Juez: Buenas razones para proponer una acepción amplia de error judicial en Chile». Revista de Derecho Público, 83 (2): 37-6o. Disponible en bit.ly/2XjpUTb.

DíAz TolosA, Regina (2014). «Ingreso y permanencia de las personas migrantes en Chile: Compatibilidad de la normativa chilena con los estándares internacionales». Estudios Constitucionales, 14 (1): 179-22o. Disponible en bit.ly/2WX9u3Y.

Dolinko, David (1985). «Is there a rationale for the privilege against self-incrimination». University of California Los Angeles Law Review, 33: 1063-1148. Disponible en bit.ly/2ATAbxQ.

DwORKIN, Ronald (1986). «We do not have a right to Liberty». En Robert Stewart (editor), Readings in Social and political Philosophy (pp. 297-305). Oxford: Oxford University Press.

Etcheberry, Alfredo (1997). Derecho penal. Parte especial. Tomo III. Santiago: Jurídica de Chile.

FALCONE, Diego (2015). «El delito de negativa injustificada de un conductor a someterse a los exámenes de detección de alcohol o sustancias estupefacientes o psicotrópicas». Revista de Derecho de la Pontificia Universidad Católica de Valparaíso, 44: 143-169. Disponible en bit.ly/2TrCQVO.

Ferrada, Francisco (2009). «La constitucionalidad del artículo 149 inciso $2 .^{\circ}$ del Código Procesal Penal». Revista de Estudios de la Justicia, 11: 343-367. Disponible en bit.ly/3geesRo.

Feurbach, Paul Johann Anselm (1989). Tratado de Derecho Penal Común Vigente en Alemania. Trad. por Eugenio Zaffaroni e Irma Hagemaier. Buenos Aires: Hammurabi.

Foucault, Michel (2007). Historia de la sexualidad I: La voluntad de saber. México: Siglo XXI.

Galanter, Marc (1969). "The Modernization of Law». En Lawrence Friedman y Stewart Macaulay (editores), Law and the behavioral Sciences (pp. 989-998). Indianápolis: Bobbs Merril.

GaldÁmeZ, Liliana (2014). «Algunos criterios del Tribunal Constitucional sobre el estatuto jurídico de las personas extranjeras en Chile». Revista Chilena de Derecho y Ciencia Política, 5 (3): 119-134. Disponible en bit.ly/3eexup1. 
Garrido MontT, Mario (1999). «La indemnización por error judicial en Chile». Ius et Praxis, 5 (1): 473-482. Disponible en bit.ly/3g98qAz.

-. (2010). Derecho penal. Parte especial. Tomo III. Santiago: Jurídica de Chile.

GonzÁLEz, Felipe y Cristián Riego (1994). «Las garantías de la detención en Chile». En Proceso penal y derechos fundamentales (pp. 195-239). Santiago: Corporación Nacional de Reparación y Reconciliación.

HenríqueZ Viñas, Miriam (2014). «El habeas corpus como un recurso idóneo para garantizar la libertad personal de los migrantes. Análisis jurisprudencial (20092013)». Ius et Praxis, 20 (1): 365-376. Disponible en bit.ly/2WTEe5A.

-. (2018). «El habeas corpus contra las expulsiones ilegales y arbitrarias de migrantes». Revista de Derecho Aplicado LLM UC, 1: 1-18. Disponible en bit.ly/3ghihVI.

Hilbink, Lisa (2007). Judges Beyond Politcs in Democracy and Dictatorship: Lessons from Chile. Nueva York: Cambridge University Press.

Horvitz, María Inés y Julián López (2003). Derecho procesal penal chileno. Tomo I. Santiago: Jurídica de Chile.

Irarrázabal, Paz (2015). «Igualdad en las calles en Chile: El caso del control de identidad». Política criminal, 10 (19): 234-265. Disponible en bit.ly/2WSOr2n.

Lawson, Delfina y Macarena Rodríguez (2016). «El debido proceso en los procedimientos de expulsión administrativa de migrantes: Situación actual y alternativas». En Informe Anual sobre Derechos Humanos en Chile 2016 (pp. 217-238). Santiago: Universidad Diego Portales.

López-Morales, Ernesto (2013). "Gentrificación en Chile: aportes conceptuales y evidencias para una discusión necesaria». Revista de Geografía Norte Grande, 56: 31-52. Disponible en bit.ly/3cRivuF.

Moore, Michael (1993). Act and crime: The philosophy of action and its implications for criminal law. Oxford: Clarendon Press.

Nagel, Thomas (2005). «The problem of global justice». Philosophy \& Public Affairs, 33 (2): 13-147. Disponible en bit.ly/3gcFvwl.

-. (2008). «Poverty and food: Why charity is not enough». En Thomas Pogge y Darrel Moellendorf (editores), Global Justice: Seminal Essays (pp. 49-59). Saint Paul: Paragon House.

Nogueira, Humberto (1999): «El derecho a la libertad personal y seguridad individual en el ordenamiento jurídico chileno». Ius et Praxis, 5 (1): 289-337. Disponible en bit.ly/3g8VbAR.

-. (2003): «El principio de reserva legal en la doctrina emanada del Tribunal Constitucional». Ius et Praxis, 9 (1): 541-544. Disponible en bit.ly/3eagcJr.

-. (2005): «Aspectos de una teoría de los derechos fundamentales: La delimitación, regulación, garantías y limitaciones de los derechos fundamentales». Ius et Praxis, 11 (2): 15-64. Disponible en bit.ly/2XoHO6K. 
Nussbaum, Martha (1999). Women and Human Development: The Cappabilities Approach. Nueva York: Cambridge University Press.

Pettit, Philip (1997). Republicanism. A theory of freedom and government. Oxford: Clarendon Press.

Radin, Margaret (1986). «Residential rent control». Philosophy \& Public Affairs, 15 (4): 350-38o. Disponible en bit.ly/3ggHKPp.

RaWLs, John (2001). The law of peoples: With «the idea of public reason revisited». Cambridge: Harvard University Press.

Raz, Joseph (1988). The morality of freedom. Oxford: Oxford University Press.

RojAs, Nicolás y Claudia Silva (2016): La migración en Chile: Breve reporte y caracterización. Informe del Observatorio Iberoamericano sobre movilidad humana, migraciones y desarrollo. Madrid: Observatorio Iberoamericano sobre Movilidad Humana, Migraciones y Desarrollo.

Sabatini, Francisco, María Sarella Robles y Héctor Vásquez (2013). «Gentrificación sin expulsión, o la ciudad latinoamericana en una encrucijada histórica». Revista 18o, 24: 18-25. Disponible en bit.ly/2TvX3ty.

Schmitt, Carl (2009). Teología Polític. Madrid: Trotta.

TAYLOR, Charles (1986). "What's wrong with negative Liberty». En Robert Stewart (editor), Readings in Social and political Philosophy (pp. 100-112). Oxford: Oxford University Press.

Valenzuela, Jonatan (2015). Informe en Derecho. Omisión de dar cuenta a la autoridad policial y negativa injustificada a someterse a exámenes corporales desde una perspectiva constitucional y procesal. Santiago: Defensoría Penal Pública.

Vodanovic, Natalio (2005). «Aspectos de las indemnizaciones por error judicial y por conductas erróneas del ministerio público, con el nuevo sistema procesal penal». Revista de Derecho Consejo de Defensa del Estado, 13: 209-214. Disponible en bit.ly/2ATH6ag.

WALDRON, Jeremy (2009). «Homelessness and the issue of freedom». UCLA Law Review, 39: 295-324. Disponible en bit.ly/2TuZQTX.

ZÚÑIGA, Francisco (2008). «La acción de indemnización por error judicial: reforma constitucional. Regulación infraconstitucional y jurisprudencia». Estudios Constitucionales, 6 (2): 15-41. Disponible en bit.ly/3bYsVoi.

\section{Reconocimientos}

Agradezco enormemente la ayuda editorial y los comentarios de Diego Rochow, así como de los revisores anónimos de la Revista de Estudios de la Justicia. 


\section{Sobre la autora}

Rocío Lorca Ferreccio es abogada, doctora en Derecho y profesora de la Facultad de Derecho de la Universidad de Chile. Su correo electrónico es rlorca@derecho. uchile.cl. 
La Revista de Estudios de la Justicia es publicada, desde 2002, dos veces al año por el Centro de Estudios de la Justicia de la Facultad de Derecho de la Universidad de Chile. Su propósito es contribuir a enriquecer el debate jurídico en el plano teórico y empírico, poniendo a disposición de la comunidad científica el trabajo desarrollado tanto por los académicos de nuestra Facultad como de otras casas de estudio nacionales y extranjeras.

\author{
DIRECTOR \\ Álvaro Castro \\ (acastro@derecho.uchile.cl) \\ SITIO WEB \\ rej.uchile.cl \\ CORREO ELECTRÓNICO \\ cej@derecho.uchile.cl \\ LICENCIA DE ESTE ARTÍCULO \\ Creative Commons Atribución Compartir Igual 4.o Internacional
}

La edición de textos, el diseño editorial

y la conversión a formatos electrónicos de este artículo

estuvieron a cargo de Tipográfica

(www.tipografica.io). 